\title{
Pulp fictions \\ of medieval \\ England
}

\section{Essays in popular romance}

\section{Nicola McDonald}

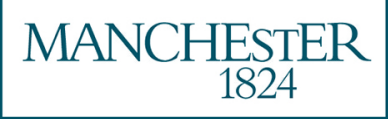

Manchester University Press 


\section{Pulp fictions of medieval England}

Published in our centenary year

$\approx 2004 \cong$

MANCHESTER

UNIVERSITY

PRESS 
Nicola McDonald - 9781526137593

Downloaded from manchesterhive.com at 04/26/2023 09:37:16AM 


\section{Pulp fictions of medieval England}

Essays in popular romance

edited by

Nicola McDonald

Manchester University Press

Manchester and New York

distributed exclusively in the USA by Palgrave 
While copyright in the volume as a whole is vested in Manchester University Press, copyright in individual chapters belongs to their respective authors.

This electronic version has been made freely available under a Creative Commons (CC-BY-NC-ND) licence, which permits non-commercial use, distribution and reproduction provided the author(s) and Manchester University Press are fully cited and no modifications or adaptations are made. Details of the licence can be viewed at https://creativecommons.org/licenses/by-nc-nd/3.0/

Published by Manchester University Press Oxford Road, Manchester MI 3 9NR, UK and Room 400, I75 Fifth Avenue, New York, NY Ioo Io, USA www.manchesteruniversitypress.co.uk

British Library Cataloguing-in-Publication Data

A catalogue record for this book is available from the British Library

Library of Congress Cataloging-in-Publication Data applied for

ISBN O 7I90 63I 83 hardback

0 7I90 63I9 I paperback

First published 2004

II $\begin{array}{llllllllllllllllll}\text { IO } & 09 & 08 & 07 & 06 & 05 & 04 & \text { IO } & 9 & 8 & 7 & 6 & 5 & 4 & 3 & 2 & \text { I }\end{array}$

The publisher has no responsibility for the persistence or accuracy of URLs for any external or third-party internet websites referred to in this book, and does not guarantee that any content on such websites is, or will remain, accurate or appropriate.

Typeset in Bembo by

Koinonia, Manchester 